\title{
Impact of Educational Program for Hepatic Encephalopathy on Nurses` Performance and Patients`Outcomes
}

\section{Hanem Saad Mahmoud ${ }^{1}$, Labiba Abd Elkader Mohammed ${ }^{2}$, Amal said Taha ${ }^{3}$ and Samah EI Sayed Ghonaem ${ }^{4}$}

(1) Assistant lecturer of Medical Surgical Nursing, Faculty of Nursing - Beni seuf University, (2)Professor of Medical Surgical Nursing, Faculty of Nursing - Cairo University,(3\&4) Professor of Medical Surgical Nursing, Faculty of Nursing Benha University

\section{Abstract:}

Background: Hepatic Encephalopathy (HE) is life-threatening complication of liver disease occurs with liver failure and may result from the accumulation of ammonia and other toxic metabolites in the blood. Aim of the study: Was to evaluate the impact of educational program for hepatic encephalopathy on nurse's performance and patient's outcomes. Research design: A quasi-experimental research design will be utilized. Sample: All the available nurses (40) who are caring for patients with hepatic encephalopathy regardless of their age and years of experience. Sample sizes of at least 50 patients with hepatic encephalopathy. The study was conducted at Intensive Care Units at Benha University Hospital. Tools were obtained through three main tools; Structured Interview Questionnaire Sheet, Nurse's Observational Checklist for hepatic encephalopathy care and Patient's Outcomes Sheet. Results: There is a highly statistically significant difference between knowledge and practice of studied subjects pre, immediate after implementation and 3 month post implementation of designed hepatic encephalopathy program $(\mathrm{P}<0.000 * *)$. There was a highly statistically significant difference between nurse's performance and patient outcome of designed hepatic encephalopathy program. Recommendation: Educational programs for nurses in ICU should be continuous for improve nurse's level.

Key words: Nurses' Performance, Hepatic encephalopathy, Patient outcomes

\section{Introduction:}

Hepatic Encephalopathy (HE) is a decline in brain function that occurs as a result of severe liver disease .In this condition, liver can't adequately remove toxins from blood. This causes a buildup toxins in blood stream, which can lead to brain damage. Hepatic encephalopathy is a syndrome usually observed in patients with cirrhosis. It is characterized by personal changes, intellectual impairment and depression in level of consciousness, 
it also described in patients with cirrhosis. (Batterwarth, 2016).

Hepatic encephalopathy (HE) is a hallmark of liver failure. HE manifests as a spectrum, ranging from minimal disturbances in mental function that impact on attention, cognition and quality of life to coma. Egypt had the highest age-standardized mortality rate for cirrhosis. Liver cirrhosis is the end-stage of different chronic liver diseases, and is often neglected until complications, such as hepatic encephalopathy occur (Hadjihambi, Arias, Sheikh and Jalan, 2017); (Wong and Huang, 2018).

Precipitating factors of HE include renal failure, electrolyte imbalance, esophageal varices, constipation, infection, medication non-compliance, excessive dietary protein intake, dehydration, consumption of alcohol, or consumption of certain sedatives, analgesics .In some cases, hepatic encephalopathy may occur following the creation of a transjugular intrahepatic portosystemic shunt (TIPS) ( Kenston, Song, LiZ and Zhao ,2018).

Nurses play a fundamental role in critical care unit because they are responsible for care patient, medication administration, and response to problems inherent in therapy. Agency protocols may differ and should be followed, monitoring for complications, comfort, and education. . Nurses have a critical role to play in prevention efforts and they are an important to study their level of knowledge, attitudes, and behavior regarding disinfection (Garrick, Kliger \& Stefanchik, 2012).

\section{Significant of the study}

Hepatic encephalopathy occurs as complications of advanced liver disease $30-45 \%$ of patients with cirrhosis develop to HE. In the case of chronic liver disease, as it tends to have an insidious onset, most patients do not seek treatment until late in the course of the disease develop complications. According to the World Health Organization WHO (2017) Liver Disease Deaths in Egypt rank number one in the world.

It was noticed by the researcher during clinical practice that nurses' had insufficient level of knowledge and unsatisfactory level of performance during caring of patients with Hepatic encephalopathy, which could reflect on the patient's outcomes. The researcher's observations were supported by literature review, whereas in literature, poor practice and knowledge of nurses caring with patients could affect on their patients' outcome.

\section{Aim of the study:}

This study aimed to evaluate the impact of educational program for hepatic encephalopathy on nurse's performance and patient's outcomes.

\section{Research hypothesis:}

H1: Nurses performance (knowledge and practice) score after implementing educational program will be higher than before. 
$\mathrm{H} 2$ : the patient's outcomes will be improved after implementing educational program than before.

\section{Subjects and methods}

\section{Research design:}

A quasi-experimental research design will be utilized. Quasiexperimental studies are conducted to examine the impact of educational program on nurse's performance and patient's outcomes.

\section{Setting:}

The current study was conducted in Intensive Care Units at Benha University Hospital.

\section{Sample:}

Sample size: Sample sizes of at least 50 patients with hepatic encephalopathy in Intensive Care Units during data collection time (one group) pre and posttest.

- All the available nurses (40) who are caring for patients with hepatic encephalopathy.

\section{Tools of data collection:}

Three tools were used for data collection related to this study:

(I) Structured Interview Questionnaire: It was a questionnaire administered to the nurses. It developed by the researcher, based on reviewing of past and present local and international related literatures, books, articles, internet, periodicals and magazines and translated into Arabic language. . It was used to assess nurse's knowledge about hepatic encephalopathy. It composed of two parts

\section{Part one: Demographic characteristics of nurses: -}

It consists of 6 questions about the studied nurses' characteristics including nurse's age, level of education, years of experience and previous training.

Part two: Nurses' Knowledge about hepatic encephalopathy:-

It was designed to assess nurses 'level of knowledge. It was guided by Ahmed (2018) and was modified by the researcher based on reviewing of past and present local and international related scientific literatures and theoretical knowledge of the various aspects of the study the sheet consists of 40 questions, in the form of multiple choice questions (MCQs) and true or false.

\section{II) Nurses' Observational Checklist for} hepatic encephalopathy care:

This tool adapted from (Lynn, Taylor\& LeBon 2011) and was modified by the researcher. It was used to assess nurses' practice regarding management of patient with hepatic encephalopathy. It was include nurses' practices as assessment level of consciousness using glasgow coma scale, retention enema, nasogastric tube, oral care and hygienic care.

\section{III) Patient's Outcomes Sheet:}

It was developed by researcher based on recent literature review and it divided into two parts. part one include patient demographic data, medical data and part 
two include patient physical status as physical assessment ,consciousness level, activity level of hepatic encephalopathy patients.

Content validity was tested through panel of 3 experts from Faculty of Nursing, Cairo University and 2 experts from Faculty of Nursing, Benha University to ensure its validity for comprehensiveness, accuracy, clarity and relevance.

Content reliability of tools was tested by using a Cronbach's Alpha for Structured Interview Questionnaire Sheet was reliable at (0.89), observational checklist was reliable at (0.91) and Patient's Outcomes Sheet was reliable at (0.87).

\section{Ethical consideration:}

The researcher clarified the objective and aim of the study to the nurses and patients included in the study. The researcher assured maintaining anonymity and confidentiality of the subject data. Nurses were informed that they allowed choosing to participate or not in the study and that they have the right to withdraw from the study at any time without giving any reasons.

\section{Pilot study:}

A pilot study was carried out on three nurses from the study subjects to test the clarity, applicability, feasibility and relevance of the tools used and to determine the needed time for the application of the study tools. The necessary modification done according to result of the pilot study.

\section{Field work:}

Permission to carry out this study was obtained from responsible authorities in the Faculty of Nursing after explanation of the purpose of the study was obtained. The data was collected throughout three phases of assessment for nurses. The first phase of assessment was collected prior to conducting program for nurses using the two tools to have base line of data about nurses' knowledge and practice. The second phase was done immediately post implementation of program to evaluate the effect. The third phase follows up after 3 month after implementation the program.

For patient data was collected throughout two phases of assessment pre and posttest by using three tools (patient outcome tool). The first phase of assessment was collected prior to conducting the program for nurses at patient admission to ICU. The second phase of assessment was collected immediately after implementation of program.

\section{Statistical Design:}

The collected data were organized, categorized, tabulated and statistically analyzed using the statistical package for social science (SPSS) version (20) to assess nurses` level of knowledge, practice and attitude regarding prevention of hepatitis $\mathrm{c}$ virus in hemodialysis unit 


\section{Outcomes}

\section{Results}

Table (1) shows that $72.5 \%$ of studied nurses were in age group from 20 to $<30$ years with mean $30.21 \pm 9.51$. Also $65 \%$ of the studied nurses were females; $80 \%$ were graduated from technical institute of nursing $62.5 \%$ had less than 5 years of experience and none of the studied nurses attended any training program.

Table (2) shows that there is a high statistically significant difference between total knowledge among studied nurses pre, immediate post implementation of designed hepatic encephalopathy program $\left(\mathrm{X}^{2} 1=31.42, \mathrm{P}<\right.$ $\left.0.000^{* *}\right)$ as well pre and follow up $\left(\mathrm{X}^{2} 3\right.$ $=22.06, \mathrm{P}<0.000 * *)$.

Figure (1) presents that $87.5 \%$ of studied nurses' performance was competent immediately after implementing the program and $82.5 \%$ after follow up. While $77.5 \%$ of studied nurses had incompetent performance before implementing the program.
Table (3) shows that $50 \%$ of studied patients were in age group above $50 \mathrm{yrs}$. with mean $38.52 \pm 7.32$. Also $70 \%$ of the studied patient were males, $60 \%$ were married, 40\%illiterate, as well as doesn't work and coming from urban area.

Figure (2) presents that there is $76 \%$ of studied patients are independent in activity of daily living post program while was only $4 \%$ pre- program among studied patients.

Table (4) shows that there is highly statistically significant difference between studied nurses performance and studied patients outcome pre and post implementation of designed hepatic encephalopathy program $\left(\mathrm{P}<0.000^{* *}\right)$.

Table (5) shows that there is highly statistically significant difference between knowledge score of studied nurses and their performance, pre, post immediate and follow up implementation of the designed hepatic encephalopathy program $\left(\mathrm{P}<0.000^{* *}\right)$. 
Table (1):- Frequency Distribution of the Studied Nurses According to their Socio-demographic characteristics $(n=40)$

\begin{tabular}{|c|c|c|}
\hline Socio-demographic Characteristics & No & $\%$ \\
\hline Age & & \\
\hline - 20 - & 29 & 72.5 \\
\hline - $30-$ & 11 & 27.5 \\
\hline - $50+$ & 0 & 00 \\
\hline Mean \pm SD & $30.21 \pm 9.51$ & \\
\hline Gender & 14 & 35.0 \\
\hline - Female & 26 & 65.0 \\
\hline Marital status & & \\
\hline - Married & 18 & 45.0 \\
\hline - Single & 22 & 55.0 \\
\hline $\begin{array}{l}\text { Education Level } \\
\text { - Technical Institute of nursing }\end{array}$ & 32 & 80.0 \\
\hline - Bachelor of Nursing & 8 & 20.0 \\
\hline $\begin{array}{c}\text { Experience Years } \\
-<5 y \text { rs }\end{array}$ & 25 & 62.5 \\
\hline - 5 - 15yrs & 15 & 37.5 \\
\hline Mean \pm SD & $10.32 \pm 3.32$ & \\
\hline $\begin{array}{l}\text { Previous Training Courses } \\
-\quad \text { No }\end{array}$ & 40 & 100 \\
\hline
\end{tabular}

Table (2):- Distribution of Nurses' Knowledge about Hepatic Encephalopathy on Pre, Immediate post and follow up Implementation of Designed Program $(n=40)$.

\begin{tabular}{|c|c|c|c|c|c|c|c|c|c|}
\hline \multirow[b]{3}{*}{$\begin{array}{c}\text { Nurses } \\
\text { Knowledge }\end{array}$} & \multicolumn{9}{|c|}{ The program implementation } \\
\hline & & \multicolumn{2}{|c|}{ Immediate } & \multicolumn{2}{|c|}{ Follow } & \multirow[b]{2}{*}{$\begin{array}{c}\mathrm{X}^{2} \mathbf{1} \\
\text { P-value }\end{array}$} & \multirow[b]{2}{*}{$\begin{array}{l}\mathrm{X}^{2} 2 \\
\mathrm{P} \text { - } \\
\text { value }\end{array}$} & \multirow[b]{2}{*}{$\begin{array}{c}\mathbf{X}^{\mathbf{2} 3} \\
\text { P-value }\end{array}$} \\
\hline & No & $\%$ & No & $\%$ & No & $\%$ & & & \\
\hline \multicolumn{10}{|c|}{ Hepatic Encephalopathy Disease } \\
\hline - Satisfactory & 15 & 37.5 & 34 & 85.0 & 29 & 72.5 & \multirow{2}{*}{$\begin{array}{c}19.01 \\
\left(0.000^{* *}\right)\end{array}$} & \multirow{2}{*}{$\begin{array}{l}1.86 \\
(0.172) \\
\end{array}$} & \multirow{2}{*}{$\begin{array}{l}9.89 \\
(0.002 *)\end{array}$} \\
\hline - Unsatisfactory & 25 & 62.5 & 6 & 15.0 & 11 & 27.5 & & & \\
\hline \multicolumn{10}{|l|}{ Patient care } \\
\hline - Satisfactory & 9 & 22.5 & 34 & 85.0 & 31 & 77.5 & \multirow{2}{*}{$\begin{array}{c}31.42 \\
\left(0.000^{* *}\right)\end{array}$} & 1.25 & \multirow{2}{*}{$\begin{array}{l}24.20 \\
(0.000 * *)\end{array}$} \\
\hline - Unsatisfactory & 31 & 77.5 & 6 & 15.0 & 9 & 27.5 & & $(0.264)$ & \\
\hline \multicolumn{10}{|l|}{ Total knowledge } \\
\hline - Satisfactory & 9 & 27.5 & 34 & 85.0 & 30 & 75.0 & \multirow{2}{*}{$\begin{array}{c}31.42 \\
\left(0.000^{* *}\right)\end{array}$} & 1.25 & \multirow{2}{*}{$\begin{array}{l}22.06 \\
\left(0.000^{* *}\right)\end{array}$} \\
\hline - Unsatisfactory & 31 & 77.5 & 6 & 15.0 & 10 & 25.0 & & $(0.264)$ & \\
\hline
\end{tabular}

$\mathrm{X}^{2} 1$ between pre and immediate post $\quad \mathrm{X}^{2} 2$ between post immediate and followup $\mathrm{X}^{2}$ 3between pre and follow-up 
Impact of Educational Program for Hepatic Encephalopathy on Nurses`Performance and Patients`Outcomes

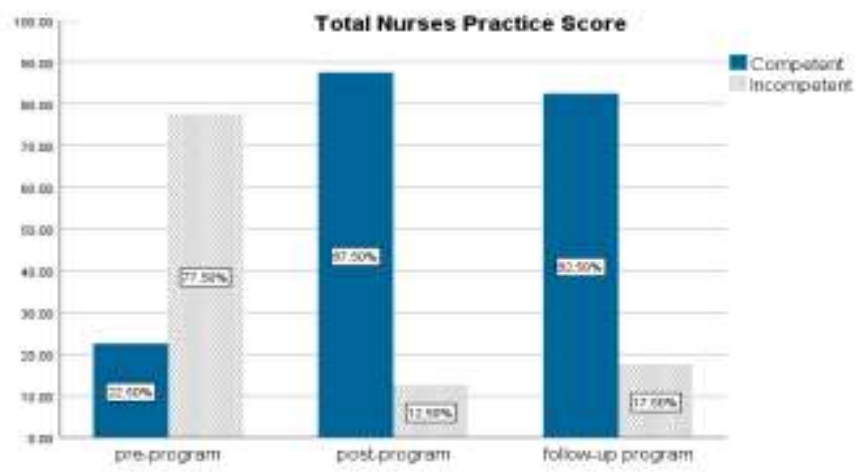

Figure (1): Frequency Distribution of Studied Nurses Regarding Total Performance Score throughout the Program Phases $(\mathrm{N}=40)$

Table (3):- Frequency Distribution of the Studied Patients According To Their Socio-Demographic Characteristics $(\mathbf{N}=50)$.

\begin{tabular}{|c|c|c|}
\hline $\begin{array}{l}\text { Socio-demographic } \\
\text { Characteristics }\end{array}$ & No & $\%$ \\
\hline \multicolumn{3}{|l|}{ Age } \\
\hline$\bullet 30-$ & 5 & 10.0 \\
\hline • $40-$ & 20 & 40.0 \\
\hline - $50+$ & 25 & 50.0 \\
\hline Mean \pm SD & $38.52 \pm 7.32$ & \\
\hline \multicolumn{3}{|l|}{ Sex } \\
\hline - Male & 35 & 70.0 \\
\hline - Female & 15 & 30.0 \\
\hline \multicolumn{3}{|l|}{ Marital Status } \\
\hline - Single & 5 & 10.0 \\
\hline - Married & 30 & 60.0 \\
\hline - Divorced & 5 & 10.0 \\
\hline - Widow & 10 & 20.0 \\
\hline \multicolumn{3}{|l|}{ Educational level } \\
\hline - Illiterate & 20 & 40.0 \\
\hline - Preparatory & 10 & 20.0 \\
\hline - Secondary & 10 & 20.0 \\
\hline - University & 10 & 20.0 \\
\hline \multicolumn{3}{|l|}{ Occupation } \\
\hline - Employer & 15 & 30.0 \\
\hline - Does not work & 20 & 40.0 \\
\hline - Retired & 10 & 20.0 \\
\hline - House wife & 5 & 10.0 \\
\hline \multicolumn{3}{|l|}{ Residence } \\
\hline - Urban & 20 & 40.0 \\
\hline - Rural & 30 & 60.0 \\
\hline
\end{tabular}




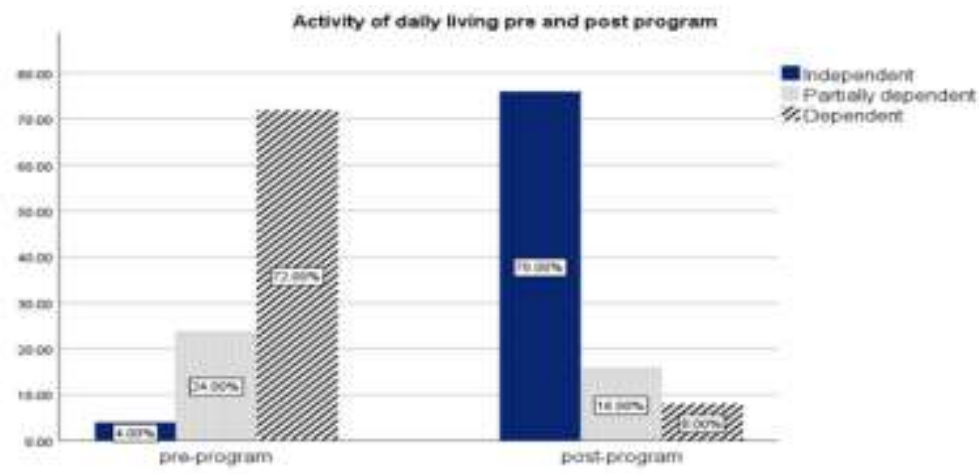

Figure (2): Frequency Distribution of Studied Patient Regarding Their Daily Living Activities Pre and Post Program (n=50).

Table (4): Correlation between Total Nurses' Performance and Patient Outcome Pre and Post Program $(n=50)$.

\begin{tabular}{|l|l|l|l|l|}
\hline \multirow{2}{*}{ Items } & \multicolumn{4}{|c|}{ Total Performance } \\
\cline { 2 - 5 } & \multicolumn{3}{|c|}{ Pre-program } & \multicolumn{2}{l|}{ Post- program } \\
\cline { 2 - 5 } & r-test & p-value & r-test & p-value \\
\hline Studied Patient outcome & 0.53 & $0.004^{*}$ & 0.74 & $0.000^{* *}$ \\
\hline
\end{tabular}

$>0.05$ insignificant $* \leq 0.05$ significant $* * \leq 0.01$ moderate significant $* * * \leq 0.001$ highly significant

Table (5): Correlation between Total Studied Nurses' Knowledge Score and Practice throughout the Program Phases $(\mathrm{N}=40)$.

\begin{tabular}{|l|l|c|l|c|c|c|}
\hline \multirow{3}{*}{ Variable } & \multicolumn{6}{|c|}{ Knowledge Score } \\
\cline { 2 - 7 } & \multicolumn{2}{|c|}{ Pre-program } & Post program & \multicolumn{2}{c|}{ Follow-up } \\
\cline { 2 - 7 } & r- test & $\begin{array}{c}\text { p- } \\
\text { value }\end{array}$ & r-test & $\begin{array}{c}\text { p- } \\
\text { value }\end{array}$ & r-test & p-value \\
\hline $\begin{array}{l}\text { Total performance } \\
\text { score }\end{array}$ & 0.31 & $0.047^{*}$ & 0.28 & 0.075 & 0.65 & $0.000^{* *}$ \\
\hline
\end{tabular}

$>0.05$ insignificant $* \leq 0.05$ significant $* * \leq 0.01$ moderate significant $* * * \leq 0.001$ highly significant

Discussion:

The current study revealed that around three quarters of the studied nurses' age were less than thirty years old, which might indicate that most of those nurses were newly graduated, 
young and tolerate the nature of the work and they are still in the fitness and power period. This finding is consistent with Abd-Elrhaman \&

Ghoneimy (2019) who assessed "Effectiveness of Educational Program Regarding Professional Nursing Ethics on Workplace Civility "which conducted at ICU units at Benha University Hospital; found that; the majority of the nurses ages ranged from 25-35 years.

Concerning studied nurse's level of education; the results of this study revealed that majority of nurses under study were having diploma degree from technical nursing institute. This finding agrees with Ahmed (2018) study entitled "Nurses' Performance regarding Management of Patients with Hepatic Encephalopathy"; his results concerning the level of education show that most of nurses were nursing Institute graduate.

Regarding nurses' knowledge about hepatic encephalopathy as definition, causes, clinical picture, types, complication and nursing management. The current study finding showed that more than three quarters of the studied nurses have unsatisfactory level of total knowledge on pre-implementation of the designed program. This result coincides with Vlaisavljevic,
Rankovic (2015) who stated that the majority of nurses in her study had unsatisfactory level of knowledge regarding hepatic encephalopathy.

A statistically significant differences in hepatic encephalopathy total knowledge (definition, clinical picture, causes, diagnostic tests, treatment and complications of hepatic encephalopathy) among studied nurses between pre and immediate post implementation of the program. As well as on immediate post and follow up implementation of designed program, the finding showed the highest level of satisfactory knowledge regarding hepatic encephalopathy as there was an improvement in studied nurses' knowledge. This could be explained that the educational program was effective as there is an improvement of studied nurses' knowledge immediately after receiving knowledge of hepatic encephalopathy sessions.

This is in agreement with study done by Mustafa \& Taha (2016) entitled " The Effect of an Educational Program on Nurses' Knowledge about Hepatitis B Virus (HBV) in Ninavah Covernorate Hospitals" who reported presence unsatisfactory level of nurse's knowledge in general information 
regard to HBV before the implementation of the educational program in pre-test. The effect of the educational program was improved throughout the acquisition of the nurse's knowledge after the implementation of the program.

It was revealed that using Glasgow coma scale (GCS) to assess level of consciousness for hepatic encephalopathy patients; there was about one quarter had competent level of practice on pre implementation of program. This could be due to lack of experience of all nurses in the study who didn't receive previous training and most of them young with few years of experience.

This study result goes in the same line of Santos et al., (2016) who study entitled" Assessment of nurse's knowledge about Glasgow coma scale at a university hospital. Einstein "explained that number of years since graduation, experience, and work at critical care units interfered with nurses' knowledge about the Glasgow coma scale, which indicates the need for training.

Regarding total nurses' practices related to nasogastric tube on pre, immediate post and follow up implementation of designed program; the present study revealed that there were high statistically significant differences between nurses' practice on pre, immediate post and follow up implementation of designed program. This could reflect the benefits of training and instructions which were provided through the program

This result is in the same line with study done by Kim\& Chang (2019) entitled as "Implementing an educational program to improve critical care nurses' enteral nutritional support" who mentioned that After the program, nurses showed a significant improvement in their practice of enteral nutrition for ICU patients

Regarding socio-demographic characteristics and medical history of hepatic encephalopathy patients; the present study revealed that the majority patients were aged more than 50 years; This explains by Kim, Kisseleva, Brenner (2015) who explain that Aging is a condition in which a person gradually loses the ability to maintain homeostasis, due to structural alteration or dysfunction, and subsequently becomes vulnerable to external stress or damage. Aging is associated with gradual alteration of hepatic structure and function as well as various changes in liver cells.

$\begin{array}{rr}\text { Regarding } & \text { correlation } \\ \text { between total nurses' Performance }\end{array}$ 
and patient outcome pre and post Program. There was a highly statistically significant difference between nurse's performance and patient outcome of designed hepatic encephalopathy program. At the same line study done by Nasr, Ameen, Mohammed, Abd El hafiz ( 2019) entitled as "Effect of an Teaching Program on Critical Care Nurses's Performance About end of Life Care for Hepatic Patients" . In their study showed that there was relation found between knowledge and practice score before and after the teaching program.

\section{Conclusion}

There were highly statistically significant improvement in knowledge of studied nurses regarding hepatic encephalopathy and practice level regarding care provided to patients when comparing with pre, immediate after and 3 month post implementation of designed program $\left(\mathrm{P}<0.000^{* *}\right)$.

\section{Recommendations}

1- Nurses should be oriented to standardized international nursing care to Hepatic encephalopathy patients.

2- Resources such as articles, Journals, Computers and internet should be accessible in the units for staff members to develop their knowledge and practices.

3- Establishing an evaluation system to monitor nurse's performance.

\section{References:}

Abd-Elrhaman, E. $\quad$ S. A.; Ghoneimy, A. G. H. (2019). Effectiveness of Educational Program Regarding Professional Nursing Ethics on Workplace Civility. ijnd 2019, 9, 13-22.

Ahmed, E.A ., (2018). Nurses' performance regarding management of patients with Hepatic encephalopathy, un published thesis, Ain Shams University, Faculty of nursing.

Butterworth R. F. (2016). Neurosteroids in hepatic encephalopathy: Novel insights and new therapeutic opportunities. The Journal of steroid biochemistry and molecular biology, 160, 94-97. https://doi.org/10.1016/j.jsbmb.2015. 11.006 .

Eldesouky, E.I(2016). Impact Of An educational Program For nurses' Knowledge And practice About Glasgow Coma Scale, International Journal of Recent Scientific ResearchVol.7, Issue,3, pp.96909695.

Garrick, R., Kliger, A., \& Stefanchik, B. (2012). Patient and 
facility safety in hemodialysis: opportunities and strategies to develop a culture of safety. Clinical journal of the American Society of Nephrology : CJASN, 7(4), 680-688. Hadjihambi,A., Natalia Arias,N., Sheikh,M., Jalan,R (2017): Hepatic encephalopathy: a critical current review, Journal of Hepatology, DOI 10.1007/s12072-017-9812-3.

\section{Kenston, F.,Song X, Li Z, Zhao} J.(2018). Mechanistic insight, diagnosis, and treatment of ammoniainduced hepatic encephalopathy. J. Gastroenterol. Hepatol.

Kim, H., \& Chang, S. J. (2019). Implementing an educational program to improve critical care nurses' enteral nutritional support. Australian critical care : official journal of the Confederation of Australian Critical Care Nurses, 32(3), 218-222.

Kim, I. H., Kisseleva, T., \& Brenner, D. A. (2015). Aging and liver disease. Current opinion in gastroenterology, 31(3), 184-191.

Mustafa, M.M \& Taha, T.H (2016).The Effect of an Educational Program on Nurses' Knowledge about Hepatitis B Virus (HBV) in Ninavah Covernorate Hospitals.
Mosul Journal of Nursing, 4(2), 8187. doi: 10.33899/mjn.2016.160041.

Nasr, N.H., Ameen, N.F., Mohammed, M.A\& Abd El hafiz,A.I.,(2019). Effect of an Teaching Program on Critical Care Nurses's Performance About end of Life Care for Hepatic Patients, Assiut Scientific Nursing Journal, Vol , (6) No, (14).

Ozisler, Z., Koklu, K., Ozel, S., \& Unsal-Delialioglu, S. (2015). Outcomes of bowel program in spinal cord injury patients with neurogenic bowel dysfunction. Neural regeneration research, 10(7), 11531158.

Santos, W. C., VanciniCampanharo, C. R., Lopes, M. C., Okuno, M. F., \& Batista, R. E. (2016). Assessment of nurse's knowledge about Glasgow coma scale at a university hospital. Einstein (Sao Paulo, Brazil), 14(2), 213-218.

Vlaisavljevic Z, Rankovic I (2015). Specific Nursing Care Rendered In Hepatic Encephalopathy: Contemporary Review and New ClinicalInsights. J Nurs Care 4: 264.

WHO (2017). available at https://www.worldlifeexpectancy.co m/egypt-liver-disease. 


\section{تأثير برنامج تعليمي عن الإعتلال الدماغي الكبدي علي أداء الممرضات ومخرجات المريض هانم سعد محمود ـ لبيبة عبدالقادر محمد ـ أمل سعيد طهـ سماح السيد غنيم}

الإعتلال الدماغي الكبدي هو أحد المضاعفات الثائعة لتليف الكبد التي تشكل خطر علي حياة المريض ويعتبر من العلامات الثائعه لحالات مرضي الفشل الكبدي. لذلك هدفت هذه الدر اسة إلى تقييم تأثير برنامج تعليمي عن الإعتلال الدماغي الكبدي علي أداء الممرضات ومخرجات المريض. وقد أجريت الدراسة باقسام الرعاية المركزة بمستشفى بنها الجامعى على جميع الممرضات والممرضين عددهم ( • ) و عدد المرضي ( •0) أثناء تجميع البيانات. حيث كثفت النتائج عن وجود تحسن ملحوظ فى معلومات وآداء الممرضات عن الإعتلال الدماغي الكبدي بعد تنفيذ البرنامج التعليمي. كما أوصت الدراسة بأهمية إعادة نفس الدر اسة على مجمو عة بحثية اكبر وفي اماكن مختلفة لتعميم نتائج الدر اسة. 